\title{
Diagnosis Kerusakan Bantalan Gelinding Pada Sistem Industri Dengan Metode Self Organizing Map (SOM)
}

\author{
Dega Surono Wibowo ${ }^{\mathrm{a}}$, Achmad Widodo ${ }^{\mathrm{b}}$

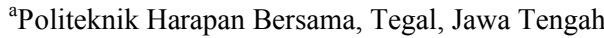 \\ burusan Teknik Mesin, Fakultas Teknik, Universitas Diponegoro
}

Naskah Diterima : 11 Januari 2014; Diterima Publikasi : 20 Maret 204

\begin{abstract}
This research is discussing about the usage of data mining which addressed to damage diagnosis of rolling bearings. Data input was obtained from signal frequency feature extraction which taken from calibration against rolling bearings. The diagnosis was extremely important to industrial machines since this diagnosis can help to discover damages that occurred so that total failure of cessation of the machines can be avoided and industrial machines treatment costs can be optimized. Method used in this research is Self Organizing Map (SOM), SOM method on this research was done by sequence: signal frequency data that have been through the process of acquisition and preprocessing, feature extraction, Principal Component Analysis (PCA), then come into the process of SOM so that accuracy of the diagnosis process can be discovered. The result of this research is a software that can diagnose rolling bearings damage on industrial system. From tests result, software that has been produced was able to diagnose rolling bearings damage. Accuracy result shown $87.5 \%$ success, this software can be developed further to help technicians in diagnosing rolling bearings damage. This research method can be developed further to detect other damages in industrial systems.
\end{abstract}

Keywords: Data mining; PCA; SOM; Diagnosis; Rolling bearings; Statistic feature extraction

\section{Abstrak}

Penelitian ini membahas tentang penggunaan data mining yang ditujukan untuk diagnosis kerusakan bantalan gelinding. Input data diperoleh dari ekstraksi ciri (fitur) sinyal getaran yang diambil dari pengujian terhadap bantalan gelinding. Diagnosis sangat penting bagi mesin-mesin industri karena diagnosis dapat membantu mengetahui kerusakan-kerusakan yang terjadi sehingga kegagalan total dari berhentinya mesin-mesin industri dapat dihindari dan ongkos perawatan mesin-mesin industri dapat dioptimalkan. Metode yang digunakan dalam penelitian ini adalah Self Organizing Map (SOM), metode SOM pada penelitian ini dilakukan dengan urutan : data sinyal getaran yang sudah melalui proses akuisisi dan pre-processing, ekstraksi fitur, Principal Component Analysis (PCA), Selanjutnya masuk ke proses SOM sehingga dapat diketahui akurasi dari proses diagnosis tersebut. Hasil dari penelitian ini adalah sebuah perangkat lunak yang dapat mendiagnosis kerusakan bantalan gelinding pada sistem industri. Dari hasil pengujian bahwa perangkat lunak yang dihasilkan mampu mendiagnosis kerusakan bantalan gelinding. Hasil akurasi menunjukkan $87,5 \%$ berhasil, perangkat lunak ini dapat dikembangkan lagi untuk membantu para teknisi dalam mendiagnosis kerusakan bantalan gelinding. Metode penelitian ini dapat dikembangkan lagi untuk mendeteksi kerusakan-kerusakan yang lain dalam sistem sistem industri

Kata kunci : Data mining; PCA; SOM; Diagnosis; Bantalan gelinding; Ekstraksi fitur statistik

\section{Pendahuluan}

Bantalan gelinding/bearing merupakan salah satu komponen utama dalam mesin-mesin industri. Bantalan gelinding merupakan alat untuk menahan atau mendukung suatu poros agar tetap berputar pada tempatnya. Pada bantalan gelinding terdapat elemen yang berputar dan juga ada elemen yang diam saat bekerja yang terletak di antara poros dan rumah bantalan gelinding. Kerusakan utama dari sebuah mesin adalah gagalnya bantalan gelinding berputar (Niu et al., 2005). Kerusakan bantalan gelinding yang tidak ditangani akan dapat mengakibatkan kegagalan dalam industri. Oleh karena itu proses

*) Penulis korespondensi: dega.wibowo@gmail.com pemantauan bantalan gelinding penting dilakukan karena untuk pemeliharaan mesin-mesin industri. Proses diagnosis dilakukan dengan cara menggunakan data-data dari sinyal getaran yang dihasilkan dari bantalan gelinding. Data sinyal getaran yang diperoleh sudah melalui pre processing, dengan adanya diagnosis dari bantalan gelinding tersebut diharapkan dapat memudahkan kita dalam mengambil keputusan terhadap mesin-mesin tersebut, sehingga dapat meningkatkan efisiensi dan efektivitas kerja suatu mesin industri.

Dengan kelebihan dari metode SOM, maka penelitian ini akan menerapkan metode SOM untuk mendiagnosis kerusakan bantalan gelinding 
berdasarkan data sinyal getaran bantalan gelinding karena dengan melakukan diagnosis akan membantu mengetahui kerusakan bantalan gelinding dari sebuah mesin sehingga bila terjadi kerusakan yang mendadak dapat dihindari, serta menghemat biaya perawatan dari mesin-mesin industri namun tidak mengurangi performa dari mesin-mesin industri tersebut.

Manfaat dari penelitian ini yaitu membantu masalah sulitnya mendiagnosis kegagalan dari bantalan gelinding yang sering terjadi pada suatu industri. Sehingga bila terjadi kerusakan yang mendadak dapat dihindari. Serta menghemat biaya perawatan dari mesin-mesin industri tetapi tidak mengurangi performa dari mesin industri tersebut.

\section{Kerangka Teori}

Diagnosis kerusakan merupakan serangkaian proses yang meliputi proses deteksi, proses isolasi dan proses identifikasi kerusakan yang terjadi dan kerusakan yang akan terjadi ketika komponen yang didiagnosis tersebut masih beroperasi dan terjadi penurunan kinerja. Diagnosis dapat dijadikan sebagai alat untuk mengambil suatu keputusan, diagnosis juga dapat dimanfaatkan untuk meningkatkan kinerja prognosis. Selain itu diagnosis dapat juga digunakan sebagai umpan balik informasi untuk mendisain ulang sebuah sistem.

Bearing atau bantalan gelinding merupakan suatu komponen yang dapat berfungsi untuk mengurangi gesekan pada mesin atau komponen-komponen yang bergerak dan saling menekan satu dengan yang lainnya.

Jika gerakan yang terjadi antara dua permukaan yang saling berhubungan tersebut terhambat, maka akan menimbulkan panas. Hambatan ini juga sering disebut sebagai gesekan (fiction). Gesekan yang terjadi secara terus menerus dapat menimbulkan panas, panas yang terjadi semakin lama makin panas sehingga dapat menyebabkan keausan pada komponen tersebut. Gesekan yang terjadi dan tidak terkontrol akan menyebabkan kerusakan pada komponen tersebut, sehingga alat tersebut tidak bisa bekerja dengan maksimal.

Pada Gambar 1 merupakan gambar dari bagianbagian bantalan gelinding. Bantalan gelinding digunakan untuk menahan komponen-komponen yang bergerak. Bantalan gelinding biasanya dipakai untuk menahan perputaran pada shaft, di mana pada perputaran shaft terjadi banyak gesekan. Fungsi dari Bantalan gelinding antara lain untuk mengurangi gesekan, panas dan aus, serta menahan beban shaft dan mesin, menahan radial load dan thrust load, menjaga toleransi kekencangan serta mempermudah pergantian dan mengurangi biaya operasional.

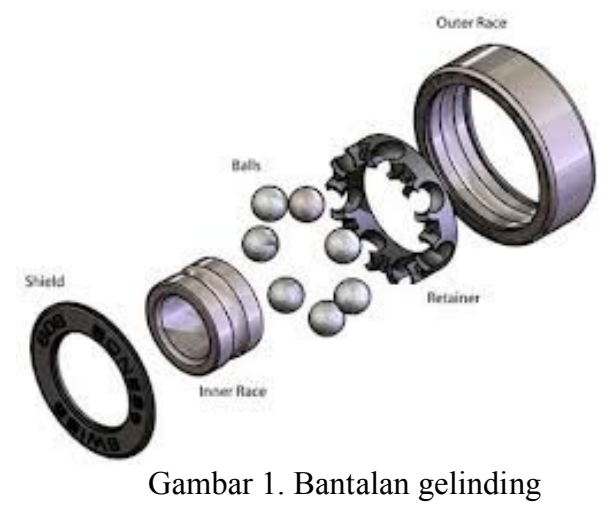

SOM pertama kali diperkenalkan oleh Kohonen di mana hanya neuron yang jadi pemenang yang diperbaharui bobotnya. SOM tidak menggunakan nilai dari target kelas, sehingga tidak ada kelas yang ditetapkan untuk setiap data. Karakteristik inilah yang kemudian membuat SOM dapat digunakan untuk keperluan pengelompokan.

Arsitektur SOM dapat dilihat seperti Gambar 2, SOM dibentuk dari layer tunggal dengan jumlah neuron pemroses yang sama dengan kelompok. Setiap data masukan mempunyai hubungan dan bobot pada setiap neuron. Komputasi sinyal keluaran tidak menggunakan inner-product, tetapi menggunakan jarak euclidean antara data masukan dengan bobot pada setiap neuron pemroses. Akumulasi sinyal yang didapat tidak perlu diaktivasi (fungsi aktivasi linear) karena fungsi aktivasi tidak berpengaruh pada pemilihan neuron pemenang yang akan memperbaharui bobotnya dan bobot tetangganya.

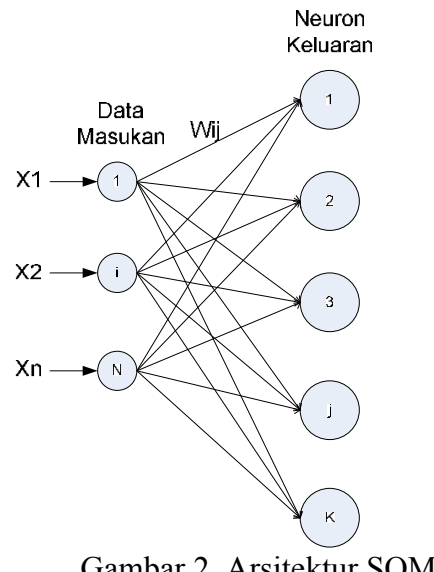

Kelompok (K) merupakan sebuah data dari hasil pengelompokan yang dilakukan oleh indeks neuron di dalam lapisannya. Sedangkan K neuron ada kelompok 1 sampai ke $\mathrm{K}$ yang merupakan hasil dari pengelompokan. Jumlah dari $\mathrm{K}$ neuron ini didefinisikan sendiri oleh pemakai. Karena tidak ada eror yang dihitung pada setiap terasi pelatihan, kriteria dari berhentinya pelatihan dari SOM adalah 
dengan menggunakan jumlah terasi tertentu. Dengan kata lain, ketika proses pelatihan SOM mencapai jumlah terasi tertentu, proses pelatihan pada SOM akan dihentikan. Masing-masing data diproses pada setiap iterasi, neuron dengan nilai keluaran terkecil akan mengalami pembaruan bobot bersama dengan tetangganya yang telah didefinisikan.

Algoritma SOM seperti berikut ini, misalkan himpunan dari $\mathrm{m}$ nilai-nilai field untuk record ke-n menjadi sebuah vektor masukan $X_{n}=X_{n 1}, X_{n 2}, X_{n 3}, \ldots, X_{n m}$, dan himpunan dari $\mathrm{m}$ bobot untuk sinyal keluaran tertentu $\mathrm{j}$ menjadi vektor bobot $w_{j}=w_{i j}, w_{2 j}, \ldots, w_{m j}$. Langkahlangkah algoritma SOM sebagai berikut (Larose 2004) :

a. Kompetisi, untuk setiap keluaran j, hitung nilai $\mathrm{D}\left(\mathrm{W}_{\mathrm{j}}, \mathrm{X}_{\mathrm{n}}\right)$ dari fungsi jarak. Tentukan simpul pemenang $\mathrm{J}$ yang meminimumkan $\mathrm{D}\left(\mathrm{W}_{\mathrm{j}}, \mathrm{X}_{\mathrm{n}}\right)$ dari semua simpul keluaran.

b. Kooperasi, merupakan identifikasi semua simpul keluaran $\mathrm{j}$ dalam lingkungan simpul pemenang $\mathrm{J}$ didefinisikan oleh lingkungan berukuran $\mathrm{R}$. Untuk simpul-simpul ini, dilakukan :

- Adaptasi, akan memperbaharui nilai bobot:

$$
w_{i j, \text { new }}=w_{i j, \text { current }}+\eta\left(x_{n i}-w_{i j, \text { current }}\right)
$$

- Perbaharui learning rate $(\eta)$ dan ukuran lingkungan (R) seperlunya.

- Menghentikan perlakuan ketika kriteria telah tercapai.

- Inisialisasi nilai bobot biasanya menggunakan nilai tengah (middle point/midpoint) atau menggunakan nilai acak (Demuth et al., 2003).

- Lingkungan berukuran $\mathrm{R}$ berisi indeks dari semua simpul-simpul yang berada dalam radius $\mathrm{R}$ dari simpul pemenang $i^{*} \cdot N_{i}(d)=\left\{j, d_{i j} \leq R\right\}$ 2003).

Pada Gambar 3 mengilustrasikan konsep lingkungan. Gambar kiri menunjukkan lingkungan dari radius $\mathrm{R}=1$ sekeliling simpul 13. gambar kanan menunjukkan lingkungan dari radius $\mathrm{R}=2$. topologi lingkungan yang digunakan ada 3, yaitu topologi grid, topologi hexagonal, dan topologi acak.

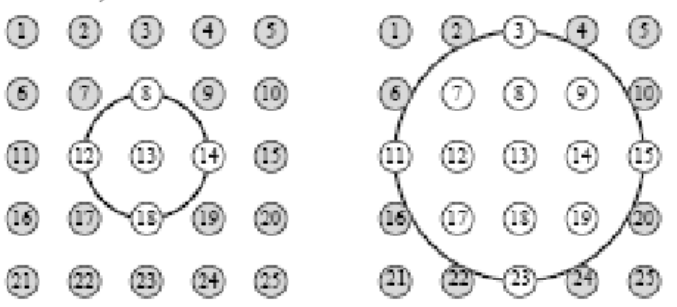

Gambar 3. Ilustrasi lingkungan
- Fungsi jarak biasanya digunakan jarak euclidean (Demuth et al., 2003).

$$
D\left(W_{j}, X_{n}\right)=\sqrt{\sum_{i}\left(W_{i j}-X_{n i}\right)^{2}}
$$

- Perubahan tingkat pembelajaran $(L R / \alpha / \eta)$ $0<\eta<1$, dengan rumus $\alpha(t+1)=\theta \alpha(t)$ Lambang $\theta$ adalah penurunan tingkat pembelajaran (PLR), yang akan menurun seiring perubahan waktu t (laurence 1994).

- Kriteria pemberhentian bisa berupa pembatasan jumlah pengulangan, atau $\eta=0$ (Larose 2004)

Pada algoritma di atas, parameter jarak untuk perbedaan atau kemiripan yang digunakan adalah jarak euclidean, hal ini dimaksudkan untuk mengurangi waktu komputasi dan menyederhanakan kinerja algoritma, tetapi harus dibayar dengan penggunaan memori yang lebih besar untuk alokasi nilai jarak yang biasanya besar.

Karakteristik dari SOM adalah dapat memvisualkan hasil pengelompokan dalam bentuk topografi dua dimensi layaknya peta sehingga memudahkan pengamatan distribusi kelompok dari hasil pengelompokan. SOM juga memerlukan penentuan fungsi ketetanggaan, laju pembelajaran, fungsi pembelajaran, jumlah kelompok dan jumlah terasi yang diinginkan, untuk penentuan parameter ini bisa digunakan cara coba-coba dengan jumlah nilai, kemudian dipilih yang terbaik. SOM hanya cocok untuk data yang sudah diketahui jumlah kelompoknya dengan mengamati bentuk alami distribusi data. SOM tidak menggunakan fungsi objektif tertentu sehingga untuk suatu kondisi yang sudah optimal pada suatu terasi, SOM tidak akan menghentikan terasinya selama jumlah terasi yang ditentukan belum tercapai. Hal ini juga berlaku ketika hasil kelompok yang didapatkan belum optimal, tetapi jumlah terasi yang ditentukan sudah tercapai sehingga hasilnya menjadi kurang sesuai dengan yang diharapkan (belum optimal).

\section{Metodologi}

\subsection{Alat Penelitian}

Alat yang dipakai untuk penelitian ini aantara lain: perangkat keras dengan Notebook $P C H P$ Pavilion DM3-1129TX dan perangkat Lunak yang digunakan adalah Windows 7 Ultimate (64 bit), Matlab R2010a (64 bit)

\subsection{Bahan Penelitan}

Bahan penelitian yang digunakan sebagai penelitian adalah data getaran bantalan gelinding dari Teknik Mesin Universitas Diponegoro. Data getaran bantalan gelinding ini sudah melalui proses pembersihan data (pre-processing). Data getaran tersebut mempunyai jumlah 16384 data yang 
nantinya di ekstraksi menjadi 21 fitur. Dari 21 fitur ini masing-masing fitur terdiri dari 160 data.

\subsection{Prosedur Penelitian}

Prosedur penelitian diagnosis kerusakan bantalan gelinding dengan menggunakan metode SOM terlihat pada Gambar 4 yaitu gambar blok diagram sistem berikut ini :

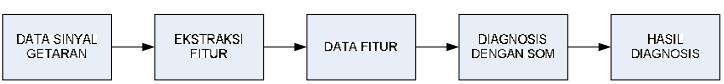

Gambar 4. Blok diagram sistem

\subsection{Analisa Sistem}

Analisa sistem dilakukan untuk mendapatkan gambaran secara lengkap mengenai permasalahan dalam sistem diagnosis. Dengan pentingnya sistem diagnosis kerusakan bantalan gelinding dengan menggunakan metode Self Organizing Map (SOM) diharapkan dapat mengolah data secara cepat dan akurat sehingga dapat memberikan informasi kerusakan bantalan gelinding pada mesin-mesin industri. Dengan informasi tepat dan akurat diharapkan dapat membantu mengambil keputusan dengan cepat.

\subsection{Desain Sistem}

Desain penelitian ini mempunyai hubungan yang erat dengan jalannya penelitian, dalam menentukan jalannya penelitian akan dijelaskan dalam metode pengembangan sistem. pemilihan metode merupakan bagian yang penting dalam pengembangan sistem. pemilihan metode pengembangan sistem hendaknya memperhatikan proses penjadwalan, tenaga, pikiran biaya dan lain-lain yang dibutuhkan dalam menyelesaikan penelitian.

Diagnosis kerusakan bantalan gelinding pada sistem industri dengan metode Self Organizing Map (SOM) dimulai dengan proses pengambilan data sinyal getaran bantalan gelinding, data sinyal getaran tersebut sudah melalui proses pengukuran, akuisisi dan pre-processing, selanjutnya melalui proses ekstraksi fitur mengelompokkan data-data getaran berdasarkan kemiripan atau kesamaan ciri yang nantinya digunakan sebagai identifikasi kesalahan lebih lanjut. Setelah dilakukan ekstraksi fitur kemudian dilakukan Principal Component Analysis $(P C A)$, PCA berfungsi untuk mereduksi fitur yang dihasilkan dari proses ekstraksi fitur. Pada penelitian ini di dalam satu kelas yang berisi 20 data akan dibagi menjadi 16 data untuk pelatihan dan 4 data untuk pengujian. Hasil dari PCA inilah yang nantinya akan masuk ke proses SOM, dari proses SOM akan mendiagnosis kerusakan-kerusakan bantalan gelinding. Jika proses SOM gagal melakukan diagnosis akan diulang kembali dari proses ekstraksi fitur.
Dari proses SOM ini akan dapat diketahui akurasi dari proses diagnosis tersebut. Akurasi diperoleh dari jumlah suatu individu yang keluar dari target kelas atau misclassify seharusnya. Kemudian dihitung akurasinya dengan melakukan pengujian per-kelas ataupun banyak kelas. Jika akurasi bagus maka proses selesai, dan jika akurasi tidak bagus kemudian mengulangi lagi akurasinya menjadi bagus. Desain sistem penelitian ini dapat dilihat seperti use case diagram Gambar 5 berikut ini :

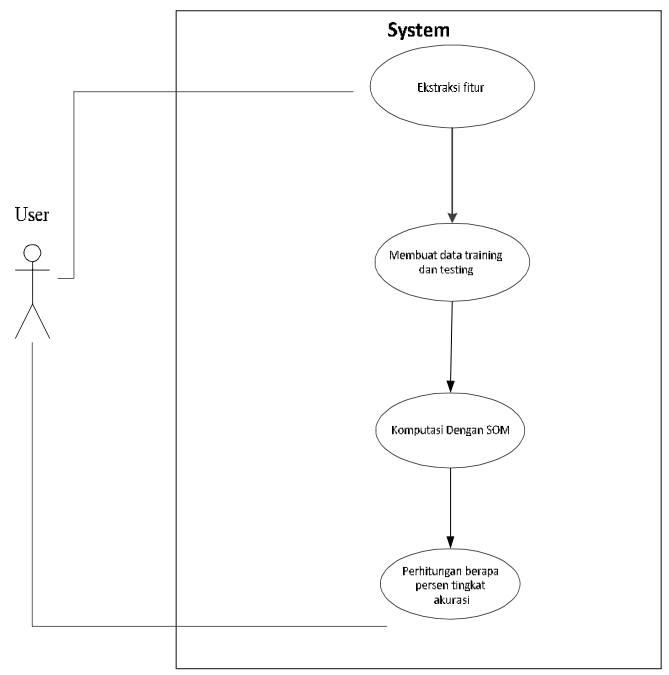

Gambar 5. Use Case diagram diagnosis kerusakan bantalan gelinding dengan SOM

Berikut ini merupakan diagram sequence yang digunakan pada penelitian ini, dalam diagram squence ini memiliki aktivitas yaitu input data getaran, di mana input data getaran tersebut akan dikalkulasikan dengan dengan fitur statistik sehingga menghasilkan fitur. Fitur-fitur yang dihasilkan kemudian di ekstraksi dengan menggunakan pendekatan principal component analysis (PCA). PCA di sini mempunyai fungsi untuk membuang data yang saling berkorelasi, sehingga data yang diperoleh tidak terlalu besar. Data hasil ekstraksi tersebut selanjutnya di bagi menjadi dua macam data yaitu data training untuk melatih model dan data testing untuk mengetes hasil klasifikasi. Aktivitas user yang berikutnya adalah menguji dengan menggunakan SOM untuk mendapatkan hasil klasifikasi yang terbaik, kemudian dihitung prosentase akurasinya, di mana hasil prosentase menentukan kondisi bantalan gelinding. Proses di atas seperti Gambar 6 di bawah ini. 


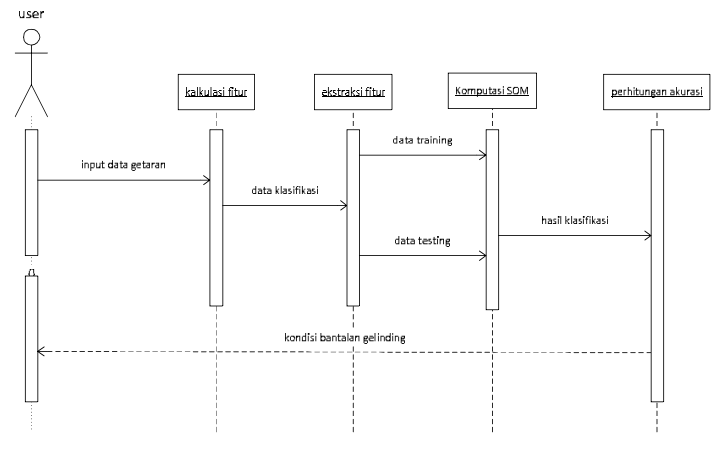

Gambar 6. Sequence diagram diagnosis kerusakan bantalan gelinding dengan SOM

\subsection{Implementasi Sistem}

Pada tahapan ini dilakukan pengembangan perangkat lunak dengan menggunakan Matlab.

a. Principal Component Analysis (PCA)

PCA bertujuan untuk mereduksi fitur sehingga semakin sedikit data algoritma data mining akan semakin cepat, akurasi dari proses data mining menjadi lebih tinggi, hasil dari proses data mining lebih sederhana sehingga lebih mudah untuk dipahami dan digunakan, semakin sedikit fitur akan membuat lebih ringkas dalam proses pengumpulan data.

b. Training (Pelatihan)

Proses pelatihan mempunyai tujuan untuk membuat sistem yang dibuat menjadi cerdas, semakin banyak pelatihan maka akan semakin cerdas pula sistem yang dibuat.

c. Testing (Pengujian)

Pengujian mempunyai tujuan untuk melihat seberapa akurat sistem yang sudah dilatih dengan format data dan metode tertentu.

d. Tampilan sistem terlihat pada gambar 7 berikut ini.

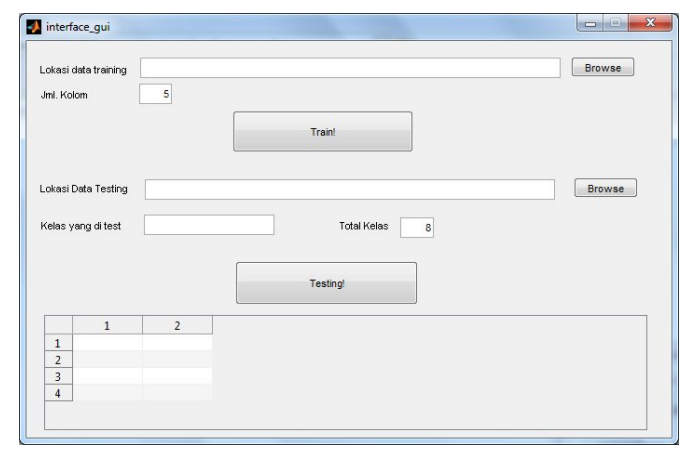

Gambar 7 Tampilan Dari Sistem

Gambar 7 merupakan gambar rancangan dari tampilan utama menampilkan lokasi data training, tombol browse, jumlah kolom, tombol train, lokasi data testing, tombol browse, kelas yang akan di test, total kelas, tombol testing, hasil klasifikasi. Cara mengisi lokasi data training dan testing ada 2 macam cara yang pertama yaitu dengan cara mengetikkan lokasi direkori dari data training maupun data testing, cara yang kedua adalah dengan menggunakan tombol browse kemudian kita pilih folder yang terdapat data training maupun data testing. Untuk mengisi kelas yang di test kita isikan 1 sampai 8, Jml Kolom diisi sesuai dengan jumlah kolom matriknya, Total Kelas diisi sesuai dengan jumlah kelasnya, sedangkan untuk tabel hasil klasifikasi akan muncul ketika tombol testing ditekan.

\subsection{Implementasi Sistem}

Pengujian sistem akan dilakukan sebelum dan sesudah aplikasi selesai dibuat. Hasil penelitian akan menunjukkan bahwa aplikasi yang sudah dibuat dapat melakukan proses perhitungan yang dirancang dan mempunyai aliran data dan informasi yang benar. Sehingga dapat menunjukkan aplikasi yang dibuat sudah benar secara logika dan sintak, sehingga dapat diterapkan secara langsung.

\section{Hasil dan Pembahasan}

\subsection{Skenario Penelitian Pertama}

Akurasi diperoleh dari jumlah suatu individu yang keluar dari target kelas atau misclassify seharusnya. Kemudian dihitung akurasinya dengan cara melakukan pengujian per-kelas ataupun banyak kelas.

Penelitian ini menggunakan data sampel yaitu data iris, data iris ini berbentuk matrik [150x4]. Data iris ini diklasifikasikan menjadi 3 kelas yaitu Setosa(Se), Versicolor(Ve), Virginia(Vg), data iris ini kemudian dipisah menjadi data pelatihan dan data pengujian yang masing-masing mempunyai matrik [135x4] untuk data pelatihan dan [15x4] sebagai data pengujian.

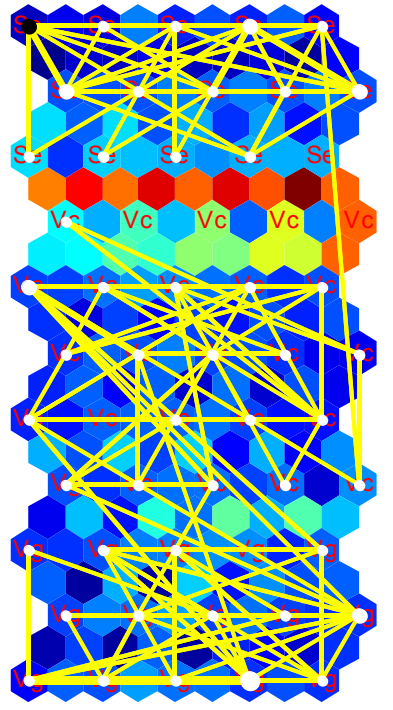

Gambar 8 U-Matrik pelatihan iris 
Tingkat Pelatihan 97,03\%, Data benar 131 data, Total data 135 data, ini seperti terlihat pada Gambar 8.

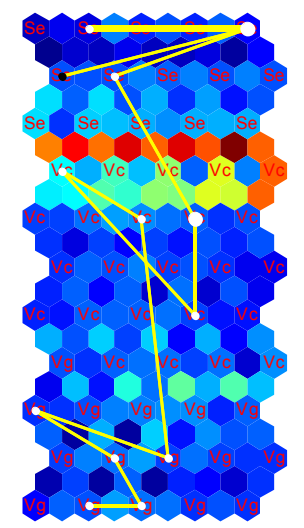

Gambar 9 U-Matrik pengujian iris

Gambar 9 menunjukkan tingkat Pengujian data iris sebesar $100 \%$, Data benar 15 data, Total data 15 data.

\subsection{Skenario Penelitian Kedua}

\subsubsection{Ekstraksi Fitur}

Percobaan ini menggunakan data getaran bantalan gelinding dari teknik mesin Universitas Diponegoro Semarang.

Data getaran bantalan gelinding ini mempunyai data sebanyak 16.384 data, dari data getaran tersebut kemudian dilakukan ekstraksi fitur, ekstraksi fitur di sini berfungsi untuk mengelompokkan data getaran tersebut berdasarkan kesamaan fitur. Hasil dari ekstraksi fitur diperoleh fitur sebanyak 21 fitur, di mana setiap fitur terdiri dari 160 data dan diklasifikasikan menjadi 8 kelas. Tiap-tiap kelas yang diklasifikasikan terdiri dari 20 data.

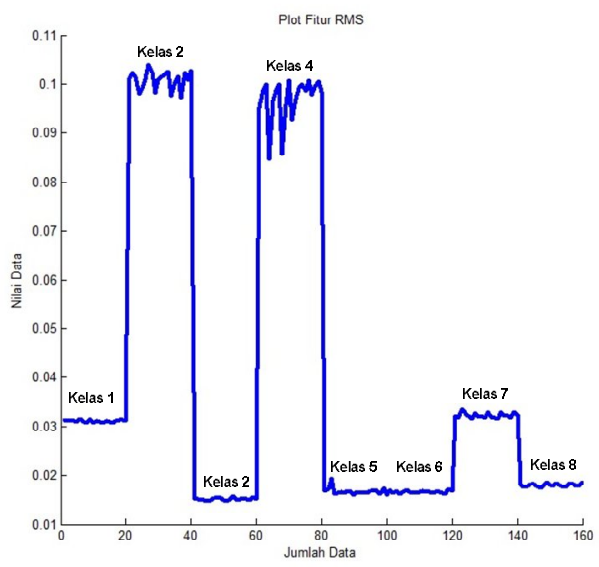

Gambar 10 Gambar plot RMS

Gambar 10 menunjukkan lokasi data dalam 1 fitur. Sumbu X disini menyatakan jumlah data dan sumbu Y menyatakan nilai data. Data yang berjumlah 160 akan direpresentasikan ke dalam bentuk yang berbeda-beda untuk tiap kelasnya. Pada Gambar 11 merupakan gambar ploting hasil dari PCA, Gambar 11 merupakan perbandingan PC1 dan PC2 pada PCA.

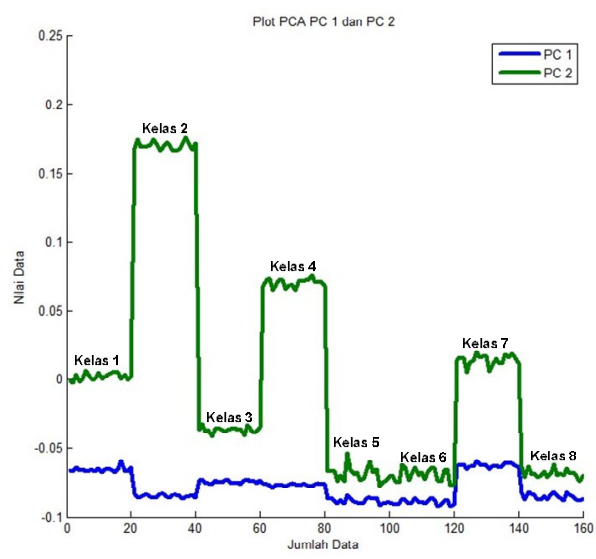

Gambar 11 Plot PC 1 dan PC 2 (PCA)

\subsubsection{Principal Component Analysis (PCA)}

PCA di sini digunakan untuk mereduksi suatu data tanpa mengurangi karakteristik dari data tersebut. Data hasil dari Principal Component adalah kurang atau sama dengan data aslinya. Dalam penelitian ini PCA digunakan untuk mereduksi 21 fitur menjadi 5 fitur. Selain mereduksi fitur PCA di sini juga mengurutkan data yang dianggap paling penting sampai data yang dianggap kurang penting. Sehingga menghasilkan [160x5].

\subsubsection{Pelatihan dan Pengujian}

Hasil dari PCA yaitu matrik [160x5], hasil dari PCA inilah yang nantinya akan dilatih dan diuji. Dari jumlah 20 data tiap kelas yang 16 data untuk pelatihan dan 4 data untuk pengujian. Sehingga diperoleh format data pelatihan [128x5] dan format data pengujian [32×5].

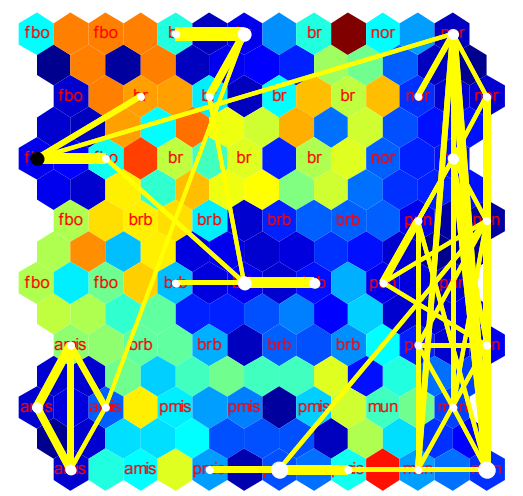

Gambar 12 U-Matrix Pelatihan Skenario Kedua 
Gambar 12 adalah gambar U-matix dari pelatihan skenario kedua, sedangkan hasil klasifikasinya dapat dilihat pada tabel 1. Dari tabel 1 dapat dilihat tingkat pelatihan dari penelitian skenario kedua adalah $87,5 \%$, dengan jumlah data benar 112 data, dari total data 128 data.

Tabel 1 Tabel pelatihan skenario kedua

\begin{tabular}{lcc}
\multicolumn{1}{c}{ Kelas } & benar & salah \\
\hline kelas 1 - amis & 16 & 0 \\
kelas 2 - br & 16 & 0 \\
kelas 3 - brb & 16 & 0 \\
kelas 4 - fbo & 15 & 1 \\
kelas 5 - mun & 11 & 5 \\
kelas 6 - nor & 7 & 9 \\
kelas 7 - pmis & 16 & 0 \\
kelas 8 - pun & 15 & 1 \\
\hline total & 112 & 16 \\
\hline
\end{tabular}

Gambar 13 merupakan gambar u-matrix pengujian skenario kedua semua kelas, hasil klasifikasinya dapat dilihat pada Tabel 2. Tabel 2 dapat dilihat hasil dari klasifikasi tingkat pengujian dari penelitian skenario kedua adalah sebesar $84,375 \%$, dengan jumlah data benar 27 data, dari total data 32 data.

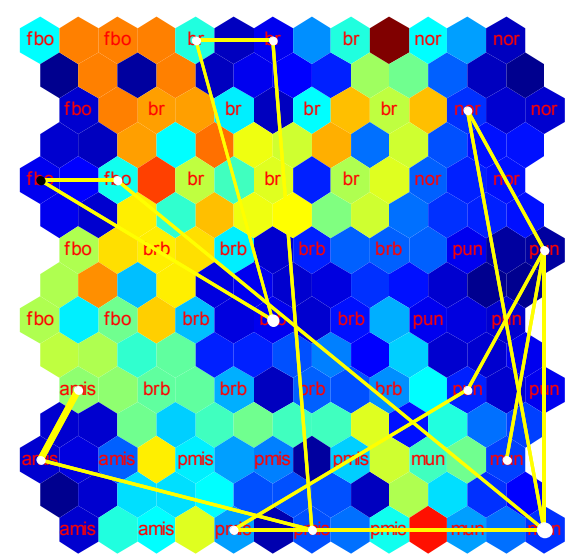

Gambar 13 U-Matrix pengujian penelitian skenario kedua

Tabel 2 Tabel Pengujian Penelitian Skenario Kedua

\begin{tabular}{lcc}
\hline \multicolumn{1}{c}{ Kelas } & benar & salah \\
\hline kelas 1 - amis & 4 & 0 \\
kelas 2 - br & 3 & 1 \\
kelas 3 - brb & 4 & 0 \\
kelas 4 - fbo & 4 & 0 \\
kelas 5 - mun & 4 & 0 \\
kelas 6 - nor & 1 & 3 \\
kelas 7 - pmis & 4 & 0 \\
kelas 8 - pun & 3 & 1 \\
\hline total & 27 & 5
\end{tabular}

\subsection{Skenario Penelitian Ketiga}

\subsubsection{Ekstraksi Fitur}

Data getaran bantalan gelinding ini mempunyai data sebanyak 16.384 data, dari data getaran tersebut kemudian dilakukan ekstraksi fitur, ekstraksi fitur di sini berfungsi untuk mengelompokkan data getaran tersebut berdasarkan kesamaan fitur. Pada skenario penelitian ketiga ini ditambahkan 4 momen statistik baru (Niu et al.,2005) untuk pendeteksian dini dari kerusakan bantalan bantalan gelinding. Hasil dari ekstraksi fitur diperoleh fitur sebanyak 25 fitur, di mana setiap fitur terdiri dari 160 data dan diklasifikasikan menjadi 8 kelas. Tiap-tiap kelas yang diklasifikasikan terdiri dari 20 data.

\subsubsection{Principal Component Analysis (PCA)}

PCA di sini digunakan untuk mereduksi suatu data tanpa mengurangi karakteristik dari data tersebut. Data hasil dari Principal Component adalah kurang atau sama dengan data aslinya. Dalam penelitian ini PCA digunakan untuk mereduksi 25 fitur menjadi 5 fitur. Selain mereduksi fitur PCA di sini juga mengurutkan data yang dianggap paling penting sampai data yang dianggap kurang penting. Sehingga menghasilkan [160x5].

\subsubsection{Pelatihan dan Pengujian}

Hasil dari PCA yaitu matrik [160x5], hasil dari PCA inilah yang nantinya akan dilatih dan diuji. Dari jumlah 20 data tiap kelas yang 16 data untuk pelatihan dan 4 data untuk pengujian. Sehingga diperoleh format data pelatihan [128x5] dan format data pengujian [32x5].

Berdasarkan pada Gambar 14 yaitu gambar umatrix pelatihan skenario ketiga. Dapat Dilihat tingkat pelatihan dari penelitian skenario kedua adalah sebesar $78,906 \%$, dengan jumlah data benar 101 data, dari total data 128 data. Rincian klasifikasinya dapat dilihat pada Tabel 3.

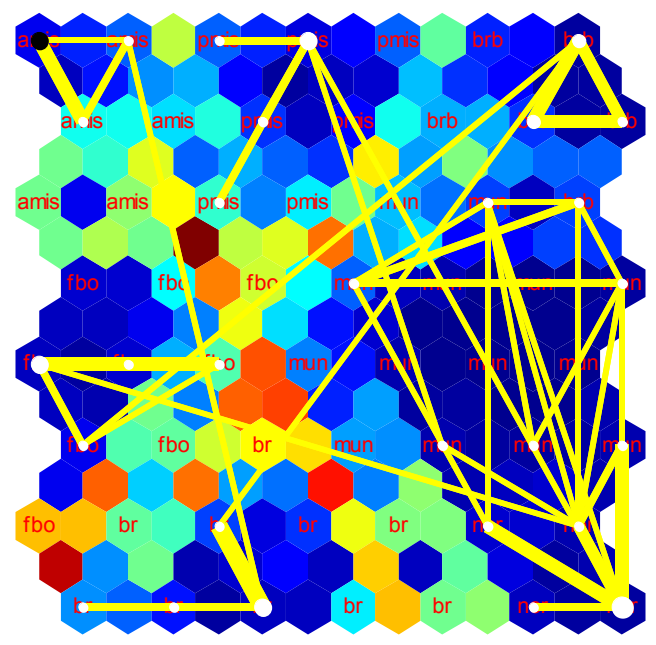

Gambar 14 U-Matrix pelatihan skenario ketiga 
Tabel 3 Tabel pelatihan skenario ketiga

\begin{tabular}{lcc}
\hline Kelas & benar & salah \\
\hline kelas 1 - amis & 16 & 0 \\
kelas 2 - br & 16 & 0 \\
kelas 3 - brb & 16 & 0 \\
kelas 4 - fbo & 16 & 0 \\
kelas 5 - mun & 6 & 10 \\
kelas 6 - nor & 15 & 1 \\
kelas 7 - pmis & 16 & 0 \\
kelas 8 - pun & 0 & 16 \\
$\quad$ total & 101 & 27 \\
\hline
\end{tabular}

Pada Gambar 15 merupakan gambar u-matrix pengujian penelitian skenario ketiga, hasil dari pengujiannya terlihat pada Tabel 4 yaitu tabel tingkat pengujian dari penelitian skenario ketiga, yang hasil dari klasifikasinya sebesar 78,125\%, dengan jumlah data benar 25 data, dari total data 32 data.

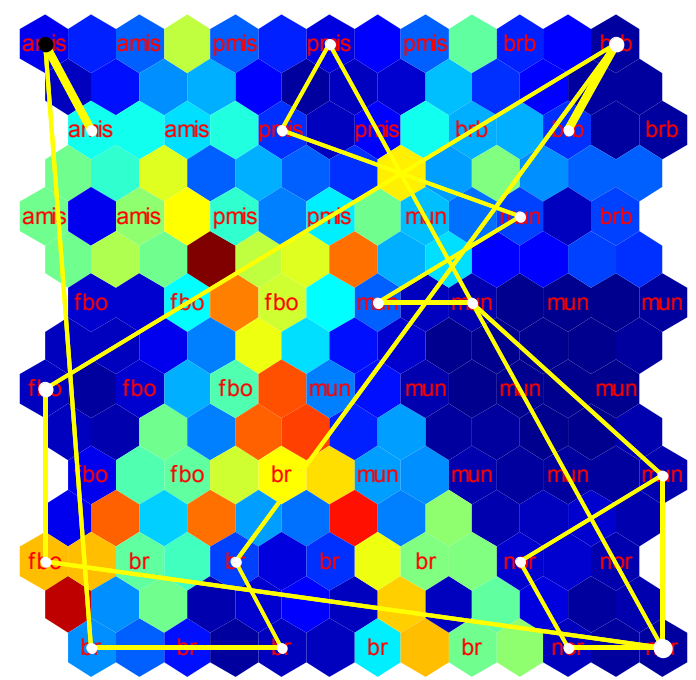

Gambar 15 U-Matrix pengujian penelitian skenario ketiga

Tabel 4. Tabel pengujian penelitian skenario ketiga

\begin{tabular}{lcc}
\hline Kelas & benar & salah \\
\hline kelas 1 - amis & 4 & 0 \\
kelas 2 - br & 4 & 0 \\
kelas 3 - brb & 4 & 0 \\
kelas 4 - fbo & 4 & 0 \\
kelas 5 - mun & 1 & 3 \\
kelas 6 - nor & 4 & 0 \\
kelas 7 - pmis & 4 & 0 \\
kelas 8 - pun & 0 & 4 \\
\hline \multicolumn{1}{c}{ total } & 25 & 7
\end{tabular}

Berdasarkan hasil dari klasifikasi yang diperoleh dari sistem dapat dihitung tingkat pengenalan pembelajaran dan tingkat pengujian dari masingmasing skenario penelitian yang telah dilakukan di atas.
Pada skenario penelitian pertama dengan menggunakan data iris sebagai contohnya diperoleh tingkat pengenalan dari data pembelajarannya sebesar 97,037\% karena dalam pengenalan pembelajarannya terdapat 131 data yang sesuai dengan kelasnya dari total 135 data. Untuk tingkat pengenalan data ujinya adalah $100 \%$ karena dalam pengenalan pengujiannya, 15 data yang diujikan ke dalam sistem seluruhnya benar masuk ke dalam kelas masing-masing.

Untuk skenario pada penelitian kedua menggunakan data getaran bantalan gelinding dari Laboratorium Teknik Mesin Undip, pada saat ekstraksi fitur menggunakan 21 fitur standar menghasilkan tingkat pengenalan dari data pembelajaran sebesar $87,5 \%$ karena dalam pengenalan pembelajarannya terdapat 112 data yang sesuai dengan kelasnya dari total 128 data. Untuk tingkat pengenalan dari data uji adalah sebesar $84,375 \%$ karena ada 5 data uji yang salah.

Skenario penelitian ketiga tetap menggunakan data uji getaran bantalan gelinding dari Laboratorium Teknik Mesin Undip, tetapi pada saat ekstraksi fitur pada skenario ketiga ini menggunakan 25 fitur yaitu 21 fitur standar dan 4 fitur tambahan dari jurnal (Niu dkk., 2005). Diperoleh tingkat pengenalan dari data pembelajarannya adalah $78,906 \%$ karena dalam pembelajarannya terdapat 101 data yang sesuai dari total 128 data. Sedangkan untuk tingkat pengenalan dari data ujinya adalah sebesar 78,125\% karena ada 7 data uji yang salah.

Tingkat pengenalan data pembelajaran dan tingkat pengenalan data uji dari skenario penelitian ke dua lebih baik dari pada skenario penelitian ketiga.

\section{Kesimpulan}

Berdasarkan hasil penelitian yang telah dilakukan, maka dapat diambil kesimpulan sebagai berikut :

a. Hasil pembahasan ini menunjukkan bahwa metode SOM cukup bagus digunakan untuk mendiagnosis kerusakan bantalan gelinding dari suatu mesin industri.

b. Untuk skenario kedua akurasi $100 \%$ ada pada kelas amis (Angular Misaligntment), brb (Broken Rotor Bar), fbo (Faulty Bearing outrace), mun (Rotor Unbalanced), pmis (Parallel Misaligntment), untuk kelas br (bowed Rotor Shaft), pun (Phase unbalanced) menunjukkan akurasi $75 \%$, dan kelas nor (Normal Motor) memiliki 25\% akurasi kebenarannya. 
c. Untuk skenario ketiga akurasi $100 \%$ ada pada kelas amis (Angular Misaligntment), br (bowed Rotor Shaft), brb (Broken Rotor Bar), fbo (Faulty Bearing outrace), nor (Normal Motor), pmis (Parallel Misaligntment), untuk kelas mun (Rotor Unbalanced) akurasinya 25\%, dan untuk kelas pun (Phase unbalanced) akurasinya $0 \%$

d. Akurasi untuk tingkat pengenalan pembelajaran dan pengujian dari skenario penelitian kedua masih lebih baik dari akurasi pembelajaran penelitian skenario ke 3, sehingga bisa disimpulkan untuk penambahan momen statistik untuk mendiagnosis bantalan gelinding belum tentu memperbaiki akurasi yang di peroleh.

e. Hasil diagnosis dalam penelitian ini dapat digunakan untuk membantu dalam pengambilan keputusan.

\section{Daftar Pustaka}

Demuth, H., Beale, M., 2003. Neural Network Toolbox For Use with MATLAB ${ }^{\circ}$. USA: The MathWorks, Inc.

Larose, D.T., 2004, Discovering Knowledge in Data: An Introduction to Data Mining, John Wiley \& Sons,Inc.

Laurence, F., 1994. Fundamentals of Neural Networks. New Jersey: Prentice Hall Inc.

Niu, X., Zhu, L. dan Ding, H., 2005, New Statistical Moments for Detection of Defects in Rolling Element Bearings, Int $J$ Adv Manuf Technol, 1268-1274. 